\title{
PENERAPAN TEKNIK LATIHAN TERPUSAT DENGAN METODE BERMAIN UNTUK MENINGKATKAN AKTIVITAS KEGIATAN PASSING ATAS DAN BAWAH BOLA VOLI
}

\author{
Sunarmi Triningsih \\ SMAN 1 Wedi Klaten
}

\begin{abstract}
Abstrak
Persoalan yang dihadapi selama proses pembelajaran permainan bola voli adalah rendahnya minat siswa pada pelajaran olah raga sehingga menyebabkan rendahnya hasil belajar siswa khususnya pada kemampuan melakukan passing atas dan bawah bola voli.

Pada umumnya siswa belum bisa melakukan passing atas dan bawah dengan benar dilihat dari beberapa faktor yaitu masih adanya rasa takut pada diri anak jika mengalami cedera saat melakukan passing, siswa kurang berani manakala bola mengarah ke arah dahi saat melambungkan bola voli, serta pembelajaran yang guru berikan kurang menarik dan kurang kreatif dalam mengembangkan pelaksanaan pembelajaran. Untuk mengatasi permasalahan tersebut maka digunakan pembelajaran dengan metode bermain.

Metode bermain merupakan bentuk pembelajaran yang mengaplikasikan teknik ke dalam suatu permainan dengan penekanan proses latihan yang menyenangkan. Penelitian ini menggunakan pendekatan penelitian tindakan kelas. Subyek dalam penelitian yaitu berjumlah 28 orang siswa kelas XII SMA. Penelitian ini dilakukan dalam 2 siklus dengan menggunakan Instrumen berupa Rencana Pelaksanaan Pembelajaran. Indikator keberhasilan peningkatan pemahaman belajar siswa pada penelitian ini dilihat dari $75 \%$ siswa tuntas KKM (dengan nilai 76). Hasil penelitian yang didapat memperlihatkan kenaikan jumlah siswa yang mencapai ketuntasan minimal di setiap siklus. Pada siklus 1 terdapat 61\% (17) siswa tuntas KKM. Pada siklus 2 terdapat $75 \%$ (21) siswa tuntas KKM. Data tersebut memperlihatkan terjadi peningkatan dari prasiklus sampai siklus 2. Keberhasilan penelitian sesuai dengan indikator keberhasilan didapat saat siklus 2, yaitu lebih dari $75 \%$ siswa tuntas KKM.
\end{abstract}

Kata kunci: metode bermain, Penjasorkes, passing atas dan bawah bola voli.

\section{PENDAHULUAN}

Pendidikan jasmani pada hakikatnya adalah pembelajaran gerak melalui aktivitas jasmani yang membentuk watak, nilai dan sikap yang dilakukan secara sadar dan sistematis. Pendidikan jasmani merupakan bagian yang tidak dapat dipisahkan dari program pendidikan. Pendidikan jasmani biasanya ditanamkan sejak usia dini dan diajarkan di sekolah dasar. Pendidikan jasmani pada anak adalah pendidikan gerak yang dilakukan dengan rasa senang dan gembira.

Pendidikan jasmani merupakan usaha pendidikan dengan menggunakan aktivitas otot-otot besar hingga proses pendidikan yang berlangsung tidak terhambat oleh gangguan kesehatan dan pertumbuhan badan (Abdul Kadir Ateng dan Adang Suherman, 1992: 4).
Menurut Samsudin (2008: 2) pendidikan jasmani adalah suatu proses pembelajaran melalui aktivitas jasmani yang didesain untuk meningkatkan kebugaran jasmani, mengembangkan keterampilan motorik, pengetahuan dan perilaku hidup sehat dan aktif, sikap sportif, dan kecerdasan emosi. Lingkungan belajar diatur secara saksama untuk meningkatkan pertumbuhan dan perkembangan seluruh ranah, jasmani, psikomotorik, kognitif, dan afektif setiap siswa.

Pendidikan memiliki sasaran paedagogis. Oleh karena itu, pendidikan kurang lengkap tanpa adanya pendidikan jasmani, olahraga, dan kesehatan. Hal ini dikarenakan gerak sebagai aktivitas jasmani adalah dasar bagi manusia untuk mengenal dunia dan dirinya sendiri yang secara alami berkembang searah dengan perkembangan zaman. Selama ini 
telah terjadi kecenderungan dalam memberikan makna mutu pendidikan yang hanya dikaitkan dengan aspek kemampuan kognitif. Pandangan ini telah membawa akibat terabaikannya aspek-aspek moral, akhlak, budi pekerti, seni, psikomotor, serta life skill.

Menurut NurilAhmadi(2013:20) permainan bola voli merupakan suatu permainan yang kompleks yang tidak mudah dilakukan oleh setiap orang. Sebab, dalam permainan bola voli dibutuhkan koordinasi gerak yang benar-benar bisa diandalkan untuk melakukan semua gerakan yang ada dalam permainan bola voli. Sedangkan menurut Suharno (2016:12) teknik adalah suatu proses melahirkan keaktifan jasmani dan pembuktian suatu praktik dengan sebaik mungkin untuk menyelesaikan tugas yang pasti dalam cabang permainan bola voli.

Oleh karena itu, pelaksanaan Pendidikan jasmani di sekolah reguler maupun pendidikan luar biasa harus benar-benar mencapai tujuannya. Penyampaiannya dapat dipermudah dengan (1) pemilihan metode ajar, (2) pemilihan materi ajar, dan (3) strategi dan model pembelajaran. Tentunya proses pendidikan jasmani di sekolah disampaikan melalui proses belajar mengajar.

Wahjoedi (2012: 121) menyatakan bahwa metode Bermain adalah pembelajaran yang diberikan dalam bentuk atau situasi permainan. Sedangkan Suherman (2013:35) berpendapat bahwa metode pembelajaran permainan berbeda dengan metode pembelajaran skill, namun bisa dipastikan bahwa keduanya harus melibatkan modifikasi atau pengembangan agar sesuai dengan prinsip DAP (Developmentally Appropriate Pactice) dan kemampuan fisik.

Menurut Sukintaka (1992: 7) bermain mempunyai sifat-sifat sebagai berikut :

1) Bermain merupakan aktivitas yang dilakukan dengan sukarela atas dasar rasa senang

2) Bermain dengan rasa senang menumbuhkan aktivitas yang dilakukan secara spontan

3) Bermain dengan rasa senang, untuk memperoleh kesenangan, menimbulkan kesadaran agar bermain dengan baik perlu berlatih, kadangkadang memerlukan kerjasama dengan teman, menghormati lawan, mengetahui kemampuan teman, patuh pada peraturan, dan mengetahui kemampuan dirinya sendiri.

Sebagai bagian integral dari sebuah penelitian, peneliti telah melakukan observasi terlebih dahulu terhadap objek kajian penelitian ini, yakni kelas XII IPA1 SMA N 1 Wedi Tahun Ajaran 2018/2019. Secara umum persoalan yang dihadapi selama proses pembelajaran permainan bola voli adalah rendahnya minat siswa pada pelajaran olahraga dan rendahnya hasil belajar siswa, khususnya pada kemampuan melakukan passing atas dan bawah bola voli.

Persoalan siswa ini terjadi karena dipicu oleh suasana belajar yang cenderung kurang menarik minat siswa dalam mengikutinya, terutama perihal metode pembelajaran yang tidak menarik. Ditambah lagi dengan pelajaran yang seringkali diberikan pada waktu-waktu di mana siswa malas untuk melakukan aktivitas.

Kondisi tersebut, akhirnya menginisiatif peneliti yang juga merupakan guru mata pelajaran olahraga untuk mengubah dan mengganti metode pembelajaran yang lebih menarik minat siswa, yakni dengan metode bermain. Metode bermain merupakan bentuk pembelajaran yang mengaplikasikan teknik ke dalam suatu permainan. Metode bermain adalah metode dengan penekanan proses latihan yang menyenangkan. Metode ini sangat cocok untuk memberikan latihan pada tahap awal sebagai langkah pertama.

Dari uraian permasalahan di atas, maka peneliti melakukan penelitian tindakan kelas dengan judul "Penerapan Teknik Latihan Terpusat dengan Metode Bermain untuk Meningkatkan Aktivitas Kegiatan Passing Atas dan Bawah Bola Voli pada Siswa Kelas XII IPA1 SMA N 1 Wedi Kecamatan Wedi Kabupaten Klaten pada Tahun Ajaran 2018/2019".

Tujuan penelitian ini adalah meningkatkan aktivitas kegiatan passing atas dan bawah bola voli siswa kelas XII IPA1 SMA N 1 Wedi Kecamatan Wedi Kabupaten Klaten.

Berdasarkan hal tersebut dapat dilihat bahwa kegiatan bermain memiliki banyak manfaat bagi 
pertumbuhan anak baik kognitif, afektif maupun psikomotor. Selain itu, kegiatan bermain juga baik bagi hubungan sosial dengan orang lain.

\section{METODE}

\section{Jenis Penelitian}

Penelitian ini menggunakan metode penelitian tindakan kelas dengan model yang ditemukan oleh Kemmis dan Taggart yang dikembangkan oleh Stephen Kemmis dan Robbin Mc Taggart (Arikunto, 2012: 16). Model ini cocok digunakan untuk penelitian tindakan kelas karena terdapat proses yang saling mengoreksi antara proses awal dan proses berikutnya sehingga menghasilkan peningkatan atau perbaikan yang diasumsikan dari awal.

Model Kemmis dan Taggart menunjukkan adanya tahapan tindakan dan observasi yang dilakukan secara simultan. Kedua kegiatan ini harus dilakukan dalam satu kesatuan waktu, begitu berlangsungnya suatu tindakan, begitu pula pengamatan juga harus dilaksanakan.

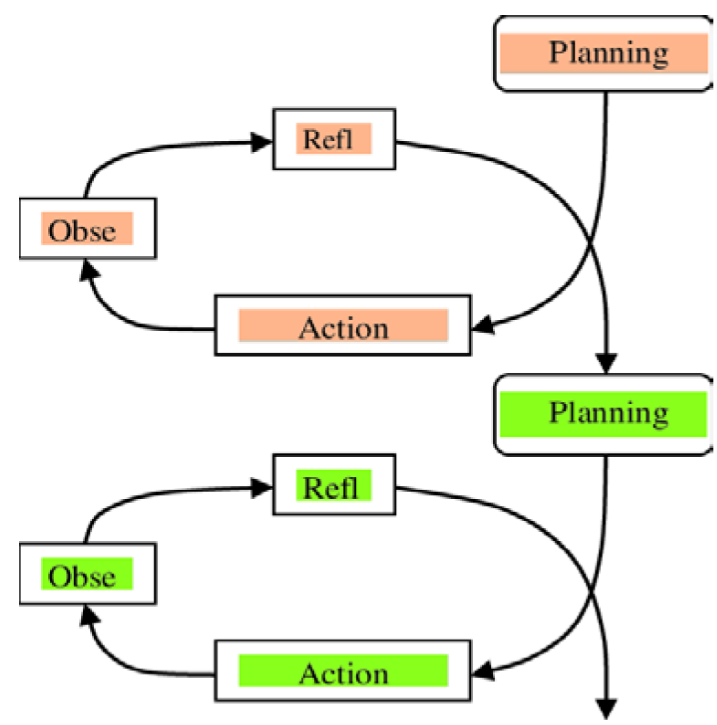

Gambar 1. Tahap PTK Metode Kemmis dan Mc Taggart

(sumber : google Action Research Model by Kemmis and Mctaggart, slideshare)

Teknik pengumpulan data yang digunakan sebagai berikut: 1) Data hasil pengamatan guru dan observer dalam melaksanakan tindakan berdasarkan lembar pengamatan, 2) Data hasil pengamatan terhadap siswa dalam proses pembelajaran yang dilakukan oleh observer, 3) Data hasil praktek materi passing bawah dan passing atas siswa.

Pengumpulan data-data yang dimaksud di atas adalah dengan teknik tes yang dilakukan pada akhir setiap siklus, kemudian data observasi yang dilakukan oleh observer dan data dokumentasi. Tes dilaksanakan pada tiap akhir siklus bertujuan untuk mengetahui hasil belajar siswa, apakah hasil yang didapatkan sudah sesuai dengan KKM yang telah ditetapkan.

Instrumen penelitian yang dipakai berupa lembar observasi dan tes unjuk kerja siswa. Lembar ini berfungsi sebagai petunjuk bagi observer dalam menilai dan mengumpulkan data selama tindakan. Adapun isi lembaran observasi ini berupa pengamatan terhadap siswa dan guru selama proses tindakan, apakah guru telah melakukan proses pembelajaran sesuai dengan RPP yang telah ditetapkan dan apakah siswa telah mengikuti pelajaran sebagaimana mestinya. Tes unjuk kerja siswa diterapkan untuk mengetahui seberapa besar perkembangan siswa dalam materi passing atas dan bawah bola voli. Hasil tes yang digunakan adalah tes yang didapatkan pada setiap akhir siklus.

\section{Subyek Penelitian}

Subyek dalam penelitian ini adalah siswa kelas XII IPA1 SMA N 1 Wedi Kecamatan Wedi Kabupaten Klaten Tahun Ajaran 2018/2019 dengan jumlah siswa 28 siswa yang terdiri dari 9 laki-laki 19 perempuan.

\section{Teknik Pengumpulan Data}

Data yang diperoleh dalam penelitian ini terdiri dari tes, pengamatan, ujian dan observasi. Tes digunakan untuk mendapatkan data tentang hasil tes passing bawah dan passing atas bola voli dengan bermain, tes tersebut digunakan untuk mengungkap aspek psikomotor dengan kemampuan siswa dalam melakukan passing bawah dan passing atas bola voli. Pengamatan digunakan untuk mendapatkan data keaktifan siswa dalam proses belajar mengajar yang meliputi aspek psikomotor. 


\section{HASIL}

Penelitian dilaksanakan selama 2 siklus, setiap siklus dilakukan 3 kali pertemuan pada setiap siklus dilakukan pengamatan. Proses penelitian di awali guru sebagai peneliti melakukan observasi terhadap proses pembelajaran passing bawah dan passing atas pada siswa kelas XII IPA1 SMA N 1 Wedi Kecamatan Wedi Kabupaten Klaten, dalam observasi tersebut ditemukan bahwa masih banyak siswa yang belum mampu melakukan passing bawah dan passing atas dengan teknik yang benar, selain itu guru juga memotivasi siswa untuk melakukan pembelajaran passing bawah dan passing atas agar siswa semangat untuk pembelajaran bola voli. Selanjutnya guru sebagai peneliti melakukan upaya peningkatan hasil belajar passing bawah dan passing atas bola voli dengan metode bermain. Dalam penelitian ini dilakukan II siklus dengan 3 kali pertemuan di setiap siklusnya.

\section{Hasil Penelitian Siklus I}

1. Perencanaan (Plan)

Seperti keterangan sebelumnya, sebuah penelitian tindakan kelas dilakukan harus terlebih dahulu dirancang tindakan-tindakan apa saja yang akan dilakukan, kemudian instrumen apa saja yang harus dipersiapkan agar data-data yang dibutuhkan bisa didapatkan dengan mudah. Penelitian ini yang dilakukan dalam upaya menerapkan metode bermain di kelas ini ada beberapa hal yang harus dipersiapkan. Beberapa hal tersebut adalah sebagai berikut: 1) Peneliti menyiapkan RPP dengan menggunakan metode bermain lengkap dengan langkah-langkah taktis dalam pembelajarannya, 2) Gerakan-gerakan berkaitan dengan materi pelajaran yang akan diberikan kepada siswa, 3) Menyiapkan lembar observasi yang akan diisi oleh observer pada saat pembelajaran, 4) Mempersiapkan sarana dan media pembelajaran yang akan digunakan dalam proses pembelajaran.

\section{Pelaksanaan Pembelajaran (Action)}

Pada tahap pelaksanaan tindakan siklus I ini dilaksanakan dalam 3 pertemuan, yaitu pada tanggal 15 Januari 2019, 22 Januari 2019 dan 29 Januari 2019.

Pertemuan 1 dilaksanakan pada hari selasa, tanggal 15 Januari 2019. Kegiatan pembelajaran dimulai dengan membuka kegiatan pembelajaran dan seperti biasa, guru memberi salam kepada siswa. Kemudian guru menunjuk salah seorang siswa untuk memimpin doa. Guru kemudian memberikan stimulus dan motivasi untuk meningkatkan semangat peserta didik. Guru menyampaikan tujuan pembelajaran dan memberitahukan bahwa proses pembelajaran akan menerapkan metode bermain.

Guru mendemonstrasikan gerakan passing atas di depan seluruh siswa dan meminta siswa memperhatikan dengan saksama. Siswa mengamati gerakan yang dilakukan oleh guru. Siswa diberi kesempatan bertanya tentang gerakan yang didemonstrasikan oleh guru tadi. Setelah itu, siswa dibagi menjadi 4 kelompok. Guru meminta semua siswa segera berkumpul dengan kelompok masingmasing. Siswa berbanjar dengan satu siswa sebagai pelempar. Pelempar bertugas melempar bola pada teman di depannya. Siswa yang dilempar langsung mem-passing bola pada pelempar, kegiatan ini dilanjutkan berulang. Guru mencatat hasil keterampilan siswa pada lembar evaluasi.

Pertemuan 2 dilaksanakan pada hari Selasa, tanggal 22 Januari 2019. Pada pertemuan 2 ini, guru melanjutkan apa-apa yang telah dimulai dari pertemuan pertama, yaitu setiap kelompok yang belum maju diminta untuk maju melakukan passing atas bola voli. Setelah selesai melakukan gerakan, guru memberikan evaluasi terhadap kegiatan pembelajaran hari ini. Guru kembali menjelaskan poin-poin penting dalam teknik passing atas bola voli.

Pertemuan 3 dilaksanakan pada hari Selasa, tanggal 29 Januari 2019. Pelaksanaan pembelajaran pada pertemuan 3, sama seperti pertemuan 1 dan 2 Guru mendemonstrasikan gerakan passing atas di depan seluruh siswa dan meminta siswa memperhatikan dengan saksama. Siswa dibagi menjadi 4 kelompok. Siswa berbanjar dengan satu siswa sebagai pelempar. Pelempar bertugas melempar bola pada teman di depannya. Siswa yang 
dilempar langsung mem-passing bola pada pada pelempar, kegiatan ini dilanjutkan berulang. Guru mencatat hasil keterampilan siswa pada lembar evaluasi.

\section{Observasi (Observation)}

Kegiatan observasi dilakukan pada saat proses pembelajaran berlangsung oleh teman sejawat guru atau observer. Dalam proses pengamatan, observer harus mengisi lembarlembar observasi yang telah disiapkan. Kemudian memuat beberapa catatan refleksi terhadap seluruh proses pembelajaran. Adapun catatan refleksi ini terdiri atas pengamatan terhadap guru, pengamatan terhadap siswa, dan refleksi/kekurangan kegiatan pembelajaran.

\section{Refleksi (Reflection)}

Dalam siklus pertama ini, observer memberikan perhatian khusus sebagai catatan refleksi untuk perbaikan terhadap beberapa kegiatan belajar mengajar yang dilakukan. Refleksi siklus I merupakan hal yang perlu menjadi perhatian dan diperbaiki pada siklus berikutnya. Di bawah ini adalah catatan yang dibuat oleh observer saat melakukan observasi pada pelaksanaan penelitian: 1) Posisi siswa dibuat berhadapan, 2) Kelompok diubah, 3) Kelompok hendaknya diatur oleh guru, 4) Minta siswa yang sudah bisa untuk mengajari teman mereka.

\section{Nilai Hasil Tes Siswa Siklus I}

Untuk akhir pertemuan pada siklus I, maka guru mempersiapkan siswa-siswa untuk melakukan gerakan passing atas untuk dinilai. Nilai hasil tes siswa siklus I adalah nilai yang didapat dari tes keterampilan melakukan gerakan passing atas pada permainan bola voli di akhir siklus I. Berikut adalah nilai hasil tes siswa pada siklus I passing atas bola voli
Tabel 1. Hasil Penilaian Siswa dalam proses aktivitas belajar siklus I

\begin{tabular}{|l|c|}
\hline Nilai Maksimal & 92 \\
\hline Nilai Minimal & 58 \\
\hline Standar Devisiasi & 54 \\
\hline Rata-rata & 77 \\
\hline Jumlah & 2165 \\
\hline Prosentase & $61 \%$ \\
\hline
\end{tabular}

Berdasarkan tabel 1 di atas dapat diketahui bahwa pada siklus I, nilai maksimal yang diperoleh siswa sebesar 92 sementara nilai minimal sebesar 58 dengan nilai rata-rata 77 serta prosentase ketuntasan sebesar 61\% (17) siswa yang tuntas KKM. Persentase tersebut masih berada di bawah indikator keberhasilan hasil tes unjuk kerja. Oleh sebab itu, penelitian tindakan kelas dilanjutkan di siklus berikutnya.

\section{Hasil Penelitian Siklus II}

\section{Perencanaan (Plan)}

Setelah kegiatan siklus I dilakukan, maka peneliti kembali mempersiapkan diri untuk melakukan siklus selanjutnya, yakni siklus II. Tahap perencanaan siklus II ini dilaksanakan untuk memperbaiki kekurangan pada siklus I seperti yang telah dipaparkan di refleksi siklus I. Adapun persiapan dan tindakan yang akan dilakukan persis sama dengan kegiatan pada siklus I, hanya saja pada siklus II ini, peneliti harus melaksanakan rekomendasi dari observer berdasarkan catatan refleksi yang telah ditetapkan.

Adapun hal-hal yang disiapkan dalam tahap perencanaan siklus II adalah RPP metode bermain, contoh gerakan-gerakan berkaitan dengan materi pelajaran yang akan diberikan, lembar observasi dan sarana serta media pembelajaran lainnya.

\section{Pelaksanaan (Action)}

Tidak jauh berbeda dengan siklus I, siklus II dilaksanakan dalam 3 pertemuan. Pelaksanaan dilakukan di kelas XII IPA1 SMA N 1 Wedi Kecamatan Wedi Kabupaten Klaten. Pelaksanaan penelitian didasarkan pada RPP siklus II yang telah dibuat di tahap perencanaan. Siklus II dilaksanakan 
pada tanggal 5 Februari 2019, 12 Februari 2019, dan 19 Februari 2019.

Pertemuan 1 dilaksanakan pada hari Selasa, tanggal 5 Februari 2019. Pelajaran dimulai dengan guru memberi salam kepada siswa, dilanjutkan dengan berdoa sebelum dimulai pelajaran. Guru mengabsen kehadiran siswa serta mengamati kesiapan siswa dalam proses pembelajaran. Guru memberikan pertanyaan-pertanyaan yang memotivasi siswa untuk mempelajari materi.

Kemudian guru menjelaskan tujuan pembelajaran yang akan dicapai pada pelajaran hari itu. Guru kembali menjelaskan bahwa kegiatan belajar mengajar akan menggunakan metode bermain. Seperti pada siklus sebelumnya, guru mendemonstrasikan gerakan passing di depan seluruh siswa dan meminta siswa memperhatikan dengan saksama. Gerakan yang ditunjukkan oleh guru kali ini adalah gerakan Passing bawah. Siswa mengamati gerakan yang dilakukan oleh guru dengan seksama. Siswa diberi kesempatan bertanya tentang gerakan yang didemonstrasikan oleh guru. Siswa dibagi menjadi 4 kelompok, satu kelompok saling berhadapan. Satu sisi bertugas melempar bola pada teman di depannya. Siswa yang dilempar langsung mem-passing bola pada pelempar, kegiatan ini dilanjutkan berulang. Guru mencatat hasil keterampilan siswa pada lembar evaluasi.

Kemudian untuk pertemuan 2 dilaksanakan pada hari Selasa tanggal 12 Februari 2019. Pertemuan 2 ini guru kembali mendemonstrasikan gerakan Passing bawah. Guru meminta setiap siswa untuk berkumpul dengan kelompok masing-masing dan mulai praktik seperti pertemuan sebelumnya. Guru memberikan arahan bila siswa kurang memahami dan kurang benar dalam gerakan Passing bawah. Guru mencatat hasil keterampilan siswa pada lembar evaluasi.

Pertemuan 3 dilaksanakan pada hari Selasa tanggal 19 Februari 2019. Langkah-langkah pada pertemuan 3 seperti pada pertemuan 1 dan 2. Guru mendemonstrasikan gerakan passing bawah di depan seluruh siswa dan meminta siswa memperhatikan dengan seksama. Siswa mengamati gerakan yang dilakukan oleh guru dengan seksama.
Siswa dibagi menjadi 4 kelompok, satu kelompok saling berhadapan. Satu sisi bertugas melempar bola pada teman di depannya. Siswa yang dilempar langsung mem-passing bola pada pelempar, kegiatan ini dilanjutkan berulang. Guru mencatat hasil keterampilan siswa pada lembar evaluasi.

\section{Observasi (Observation)}

Hasil observasi terhadap siswa yang dilakukan oleh observer dapat dilihat pada tabel 3. Kegiatan observasi dilakukan pada saat proses pembelajaran berlangsung oleh teman sejawat guru atau observer. Dalam proses pengamatan, observer harus mengisi lembar-lembar observasi yang telah disiapkan. Kemudian memuat beberapa catatan refleksi terhadap seluruh proses pembelajaran. Adapun catatan refleksi ini terdiri atas pengamatan terhadap guru, pengamatan terhadap siswa, dan refleksi/kekurangan kegiatan pembelajaran.

\section{Refleksi (Reflection)}

Refleksi pada siklus II menurut observer adalah: 1) Disiplinkan siswa yang bercanda, 2) Minta siswa untuk lebih terus berlatih teknik Passing bola voli, 3) Suara guru kurang keras, 4) Disiplinkan siswa yang bercanda, 5) Siswa nampak antusias dengan kegiatan yang dijalankan.

\section{Nilai Hasil Tes Siswa Siklus II}

Nilai hasil tes siswa siklus 2 adalah nilai yang didapat dari tes keterampilan melakukan gerakan dasar dalam Passing atas dan bawah bola voli di akhir siklus 2. Berikut adalah nilai hasil tes peserta didik di siklus II (data lebih lengkap dapat dilihat dalam lampiran).

Tabel 2. Hasil Penilaian Siswa dalam proses aktivitas belajar siklus II

\begin{tabular}{|l|c|}
\hline Nilai Maksimal & 92 \\
\hline Nilai Minimal & 67 \\
\hline Standar Devisiasi & 20 \\
\hline Rata-rata & 83 \\
\hline Jumlah & 2314 \\
\hline Prosentase & $75 \%$ \\
\hline
\end{tabular}


Berdasarkan tabel 2 di atas dapat diketahui bahwa pada siklus II, nilai maksimal yang diperoleh siswa sebesar 92 sementara nilai minimal sebesar 67 dengan nilai rata-rata 83 serta prosentase ketuntasan sebesar 75\% (21) siswa yang tuntas KKM di tahap siklus 2. Nilai kriteria ketuntasan minimal (KKM) yang ditetapkan di pelajaran PJOK SMAN 1 Wedi Kecamatan Wedi Kabupaten Klaten adalah 76. Jika di bandingkan dengan siklus I pada siklus II mengalami peningkatan.

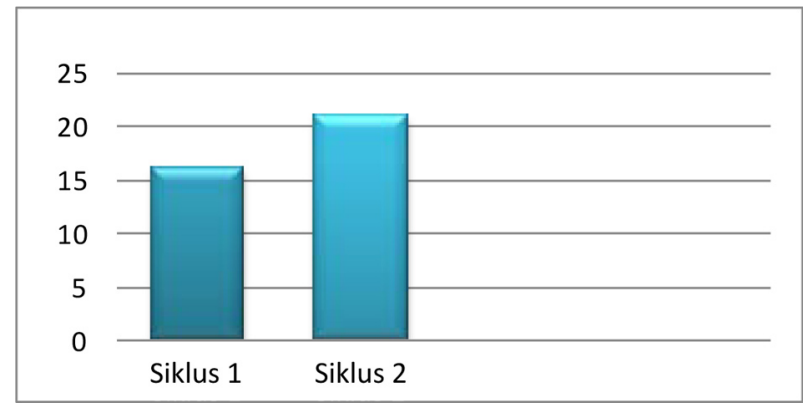

Gambar 2. Grafik Jumlah Siswa Tuntas KKM

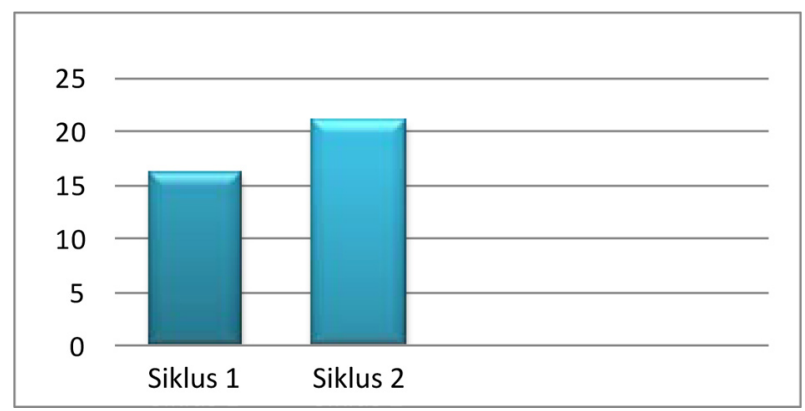

Gambar 3. Grafik Persentase Siswa Tuntas KKM

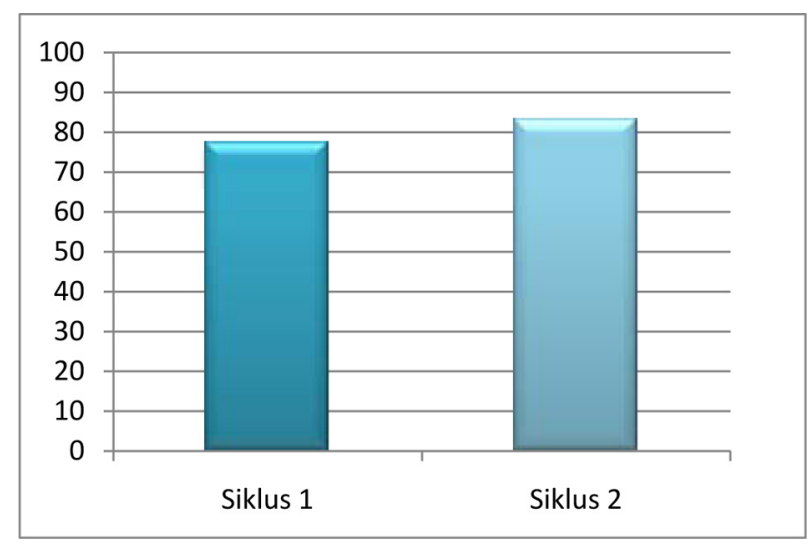

Gambar 4. Grafik Rata-rata Nilai Siswa

\section{Pembahasan}

Berdasarkan hasil yang telah diperoleh pada siklus I dari 28 siswa didapatkan 17 siswa dengan nilai antara 83-92 dengan kategori kompeten, 11 siswa dengan nilai antara 58-75 dengan kategori cukup kompeten, sehingga nilai rata-rata keseluruhan siswa adalah 77 dengan kategori cukup kompeten.

Sedangkan berdasarkan hasil yang telah diperoleh pada siklus II dari 28 siswa didapatkan 21 siswa dengan 83-92 dengan kategori kompeten, 7 siswa dengan nilai antara 67-75 dengan kategori cukup kompeten, sehingga nilai rata-rata keseluruhan siswa adalah 83 dengan kategori kompeten.

Meningkatnya aktifitas pembelajaran siswa dalam melaksanakan evaluasi terhadap kemampuan peserta didik menguasai materi pelajaran. Hal ini dapat dilihat dari nilai rata-rata siklus I 77 meningkat pada siklus II menjadi 83 dengan jumlah siswa tuntas $61 \%$ pada siklus I menjadi $75 \%$ pada siklus II.

Indikator keberhasilan penelitian ini ditentukan oleh adanya peningkatan hasil belajar tiap siklus dan adanya keberhasilan secara klasikal yang ditunjukkan dengan besarnya kelulusan. Peningkatan yang terjadi pada siklus II tak lepas dari penerapan metode bermain yang dalam proses pembelajarannya di konsep dalam bentuk permainan dimana di dalamnya dijelaskan mengenai teknik maupun taktik yang akan diberikan dengan menggunakan suatu permainan. Dengan bermain hasrat anak akan terpenuhi dan akan menambah motivasi untuk terus berlatih passing bawah dan passing atas dalam permainan bola voli.

Hasil penelitian ini menurut apa yang dilakukan oleh Rithaudin \& Hartati (2016) dalam penelitiannya bahwa hasil belajar passing bawah permainan bola voli dapat meningkat dengan menerapkannya metode permainan.

Hal yang sama juga diungkapkan oleh Yusmar (2017) dalam penelitiannya yang menunjukkan bahwa peningkatan keterampilan teknik dasar permainan bola voli dapat ditingkatkan melalui modifikasi permainan.

Semua rangkaian penelitian di atas telah di dapatkan data-data yang dibutuhkan untuk dianalisa secara mendalam. Hasil pengamatan terhadap guru pada siklus I yaitu guru belum terbiasa dalam menggunakan metode bermain pada materi passing 
bawah dan passing atas bola voli, sehingga materi yang di berikan oleh guru kurang maksimal, sedangkan hasil pengamatan pada siswa masih ada siswa yang belum mampu melakukan passing bawah dan passing atas bola voli dengan teman, dan passing bawah dan passing atas melewati net yang diberikan oleh guru. Selanjutnya guru akan mempelajari lebih dalam metode bermain sehingga tidak akan mengalami kesulitan dalam menerapkan permainan, dan guru akan lebih memotivasi dan membimbing secara intensif pada siswa yang mengalami kesulitan. Guru mencatat hasil keterampilan siswa pada lembar evaluasi.

Selesai kegiatan siklus I, maka kegiatan siklus II pun dimulai. Adapun hasil pengamatan pada siklus II menunjukkan adanya peningkatan. Meningkatnya aktifitas peserta didik dalam proses pembelajaran didukung oleh meningkatnya aktivitas guru dalam mempertahankan dan meningkatkan situasi yang menyenangkan dalam pembelajaran. Guru sudah melaksanakan rencana yang telah di susun sehingga hasil dari kegiatan siklus II mencapai peningkatan. Guru juga sudah melakukan evaluasi baik secara individu maupun secara kelompok. Guru mencatat hasil keterampilan siswa pada lembar evaluasi.

Hasil tes siswa dari tahap siklus I sampai siklus II terlihat pada tabel di bawah ini.

Tabel 3. Perbandingan Hasil Tes Siswa

\begin{tabular}{|l|c|c|}
\hline & Siklus I & Siklus II \\
\hline Jumlah siswa tuntas KKM & 17 & 21 \\
\hline$\%$ siswa tuntas KKM & $61 \%$ & $75 \%$ \\
\hline Rata-rata nilai siswa & 77 & 83 \\
\hline
\end{tabular}

Indikator keberhasilan dari penelitian ini adalah 75\% siswa tuntas KKM. Pada siklus I hanya $61 \%$ yang tuntas KKM. Hal ini terjadi karena: 1) Siswa tidak menyimak penjelasan guru, 2) Posisi siswa dibuat berhadapan, 3) Kelompok diubah, kelompok diatur oleh guru, 4) Minta siswa yang sudah bisa untuk mengajari teman mereka

Pada siklus II, guru membuat modifikasi langkah pembelajaran Bermain agar siswa lebih memahamimateriyangdiajarkan.Langkahperbaikan guru di siklus II adalah: 1) Guru mendisiplinkan siswa yang bercanda, 2) Guru meminta siswa untuk lebih terus berlatih teknik passing bola voli, 3) Guru bersuara lebih keras ketika memberi aba-aba dan penjelasan.

Hasil dari perbaikan di siklus II adalah $75 \%$ siswa tuntas KKM. Dengan rata-rata nilai tes siswa adalah 83. Dengan demikian, penggunaan metode bermain berhasil meningkatkan aktivitas kegiatan passing atas dan bawah bola voli siswa kelas XII IPA1 SMA N 1 Wedi Kecamatan Wedi Kabupaten Klaten pada pelajaran PJOK Tahun Ajaran 2018/2019.

\section{KESIMPULAN}

Berdasarkan hasil dari penelitian tindakan yang dilakukan di kelas XII IPA1 SMA N 1 Wedi Kecamatan Wedi Kabupaten Klaten dengan menggunakan metode bermain dapat disimpulkan bahwa penggunaan metode bermain berhasil meningkatkan aktivitas kegiatan passing atas dan bawah bola voli siswa kelas XII IPA1 SMA N 1 Wedi Kecamatan Wedi Kabupaten Klaten pada pelajaran Penjasorkes Tahun Ajaran 2018/2019.

\section{DAFTAR PUSTAKA}

Abdul Kadir Ateng. (1989). Pengantar Asasasas dan Landasan Pendidikan Jasmani Olahraga dan Rekreasi. Jakarta: Dirjen Dikti

Adang Suherman. (2000). Dasar-dasar Penjaskes. Jakarta: Depdiknas

Samsudin. (2008). Pembelajaran Pendidikan Jasmani Olahraga dan Kesehatan (SD/MI). Jakarta: Litera

Arikunto, Suharsimi. (2012). Prosedur Penelitian Suatu Pendekatan Praktek. Jakarta: Rineka Cipta.

Nuril Ahmadi. (2013). Panduan Olahraga Bola Voli, Surakarta: Era Pustaka Utama.

Sukintaka. (1992). Teori Bermain untuk D2 PGSD Pesnjaskes. Yogyakarta: Depdikbud

Suharno, HP. (2016). Dasar-dasar permainan Bola Volley. Yogyakarta. FPOK IKIP: Yogyakarta. 
Suherman, A. (2013). Dasar-dasar Penjaskes. Jakarta: Depdiknas.

Wahjoedi. (2012). Jurnal IPTEK Olahraga. Jakarta:

Pusat Pengkajian dan Pengembangan IPTEK (PPPITOR).

Rithaudin, A. \& Hartati, B.S. (2016). Upaya Meningkatkan Pembelajaran Passing Bawah Permainan Bola Voli Dengan Permainan Glagahombo I Tempel Sleman Yogyakarta, Jurnal Pendidikan Jasmani Indonesia, 12(1),51-57

Yusmar, A. (2017). Upaya Peningkatan Teknik Permainan, Bola Voli Melalui Modifikasi Permainan Siswa Kelas X SMA Negeri 2 Kampar, Jurnal PA-JAR (Pendidikan Dan Pengajaran), 1 (1), 143-152 